\title{
HABITAT USE BY WILD BOAR SUS SCROFA IN MONCAYO NATURE PARK, SPAIN
}

\section{Uso del hábitat del jabalí Sus scrofa en el Parque Natural del Moncayo, España}

\author{
Patrícia Rodrigues ${ }^{1,2,3}$, Juan Herrero ${ }^{4 *}$, Alicia García-Serrano 5 , Carlos Prada ${ }^{5}$, Alberto Giménez-Anaya ${ }^{4}$, \\ Raúl Ayala ${ }^{5}$, Olatz Fernández-Arberas ${ }^{5}$, Carlos Fonseca ${ }^{1}$ \\ ${ }^{1}$ Departamento de Biologia \& CESAM. Universidade de Aveiro. 3810-193. Aveiro, Portugal. patriciarodrigues@cibio.up.pt \\ ${ }^{2}$ CIBIO, Centro de Investigação em Biodiversidade e Recursos Genéticos. Campos Agrário Vairão. 4485-661. Vairão, Portugal. \\ ${ }^{3}$ IICT, Instituto de Investigação Científica Tropical. Travessa Conde da Ribeira 9. 1300 3142. Lisboa, Portugal. \\ ${ }^{4}$ Area of Ecology. Technical School of Huesca. E-22718 Huesca, Spain. herreroj@unizar.es \\ ${ }^{5}$ Ega Wildlife Consultants. Sierra de Vicort 31. E-50003 Zaragoza, Spain. egasl@arrakis.es \\ *Corresponding author
}

\begin{abstract}
Recibido: 20-05-2016. Aceptado: 06-07-2016. Fecha de publicación on-line: 07/09/2016
Citation / Cómo citar este artículo: Rodrigues, P., Herrero J., García-Serrano, A., Prada, C., Giménez-Anaya, A. Ayala, R., Fernández-Arberas, O., Fonseca, C. (2016). Habitat use by wild boar Sus scrofa in Moncayo Nature Park, Spain. Pirineos, 171, e023. doi: http://dx.doi.org/10.3989/Pirineos.2016.171007

ABSTRACT: Habitat use by wild boar Sus scrofa was examined during a three-year period in Moncayo Nature Park, a protected mountain area in the Iberian mountain system, Spain. Tracking indirect signs of activity was used to collect data on the species occurrence, according to vegetation type, topography, hunting activity, and season. The data were analysed using binary logistic regression. Habitat used by wild boar differed according seasons, management practices, and vegetation. Main selected habitats were at medium elevations $(1,101-1,600 \mathrm{~m})$ in areas dominated by holm oak (Quercus ilex), beech (Fagus sylvatica) and oak woods of Q. robur, Q. petraea and Q. pyrenaica. Non-hunting areas were selected over hunting areas. We found a seasonal variation in the habitat use of wild boar, with areas dominated by holm oak being used disproportionately in spring, and areas at medium elevations selected only during summer. The results also support the view that non-hunting areas provide a refuge for this species inside the protected area.
\end{abstract}

KEYWORDS: Binary logistic regression; Habitat selection; Hunting; Seasonal variation; Iberian mountain system.

RESUMEN: Estudiamos el uso del hábitat por parte del jabalí Sus scrofa a lo largo de tres años en el Parque Natural del Moncayo, un área protegida de montaña en el Sistema Ibérico, España. Para ello rastreamos las huellas y señales de su actividad en función de la vegetación, topografía, actividad cinegética y estacionalidad. Los datos fueron analizados utilizando regresiones logísticas binarias. El hábitat usado por el jabalí difiere según las estaciones, gestión y vegetación. Los hábitat mayoritariamente seleccionados fueron las altitudes medias (1101-1600 m) en áreas dominadas por la encina (Quercus ilex), haya (Fagus sylvatica) y robles (Q. robur, $Q$. petraea y $Q$. pirenaica). Las zonas no cinegéticas fueron seleccionadas frente a las cinegéticas. Encontramos diferencias estacionales en el uso del hábitat, con un uso mayor al esperado de los encinares en primavera 


\section{2 • PATRÍCIA RODRIGUES ET AL.}

así como de altitudes medias durante el verano. Los resultados muestran también que las zonas no cinegéticas proporcionan refugio en el interior del área protegida.

PALABRAS CLAVE: Regresión logística binaria; Selección del hábitat; Caza; Variación estacional; Sistema Ibérico.

\section{Introduction}

In recent decades, the density and distribution of wild boar S. scrofa populations have increased throughout Western Europe (Apollonio et al., 2010; Goulding et al., 2003; Sáez-Royuela \& Tellería, 1986). Multiple factors have contributed to such an increase: the species' strong plasticity, adaptability, and high reproductive rates (Macdonald, 2001), the progressive abandonment of rural areas and concomitant changes in land uses and cover (Farina, 1991), the absence of natural predators (Tellería \& Sáez-Royuela, 1985) and hunting management practices (Nores et al., 1995). In the Iberian Peninsula, hunting is a long-standing tradition with a high level of economic and social importance, where ungulates species such as the wild boar have long faced strong hunting pressure (Barbosa et al., 2004). Also, the increase of wild boar populations has led to different types of impacts and conflicts.

Wild boars can cause significant impacts on natural ecosystems (Zamora et al., 1996). Affects to biodiversity can occur by affecting the abundance and richness of both plant (through rooting behaviour and vegetation consumption), and animal communities (for example by direct predation of endangered bird species' eggs) (Massei \& Genov, 2004). Social conflicts can also emerge by ruining crops and pastures (Fernández-Llario \& Mateos-Quesada, 2003), as well as by traffic collisions. Therefore, given the increase in wild boar populations and the derived potential damages, especially in protected areas, it is essential to develop effective management approaches. In order to be effective, such approaches and management measures must be based on a true comprehensive knowledge of species population ecology and their use of habitat and resources.

Habitat use and selection is of critical importance for many species (Krebs \& Davies, 1997). It is reflected in how individuals assign their time among the different types of available habitat (Mysterud \& Ims, 1998), where the quality and quantity of resources can vary seasonally. A suitable habitat must contain a set of patches that allows individuals to engage in the activities necessary for survival and reproduction (Mysterud \& Ims, 1998; Orians \& Witenberger, 1991). Landscape structure (Acevedo et al., 2006), food availability (Massei \& Genov, 1995), climatic factors (Fernández-Llario \& Mateos-Quesada, 2005; Melis et al., 2006), social behaviour, and feeding adaptations (Morse et al., 2009) can influence habitat use by wild ungulates. For instance, in mountain environments, seasonal and elevation migrations can be a strategy to improve access to areas that have high-quality food in the case of roe deer Capreolus capreolus (Carvalho et al., 2008; Mysterud, 1999), avoid harsh weather conditions, or reduce the risk of predation. In this study, we in- vestigate habitat use by wild boar, in Moncayo Nature Park (MNP). Specifically, we address two main questions: (1) does vegetation cover, topography, or hunting activity influence the distribution of wild boar? and (2) does habitat use by wild boar vary seasonally?

\section{Materials and methods}

\subsection{Cartography and field surveys}

Between 2006 and 2008 habitat use by wild boar was assessed once per season. Seasons were defined based on climate characteristics, as follows: spring (April), summer (June), autumn (October) and winter (January). Tracking of indirect signs of activity was conducted to collect data on species occurrence (Abáigar et al., 1994). Nine itineraries were established in the field, according to three variables: elevation, vegetation, and hunting activity. Each itinerary was divided into sampling units (SU) $100 \mathrm{~m}$ long and $2 \mathrm{~m}$ wide $(\mathrm{N}=507 \mathrm{SU})$, where information was collected on the presence-absence of wild boar. The length of each itinerary varied between 2.5 and 10 $\mathrm{km}$. The surveys were conducted during the day by one observer who searched for signs of wild boars; viz, tracks, feeding and bedding signs, droppings, scrapes, wallows, and direct observations. Given that wild boars follow paths, and to assume independence of data, only oddnumbered SU were included in the analyses.

To define the habitat structure of each SU, the itineraries were digitalized using orthophotos of the study area. To obtain a SU map of the area, the itineraries and sampling units were transformed into aligned $200 \mathrm{~m}^{2}$ polygons (100 x 2 m). A Digital Elevation Model (DEM) was used to derive topographic information (elevation) by extracting the mean elevation values of each SU, using the SU centroid as the origin. An average elevation value was calculated for each $\mathrm{SU}$, which were assigned to one of three categories: 600-1100 m, 1101-1600 m, and 1601$1800 \mathrm{~m}$. Vegetation categories were defined based on a vegetation map $(1: 25,000)$ of the region (Uribe-Echevarría, 2002). The vegetation map had a high degree of detail; therefore, we reduced the categories to the following: shrubs, pastures and crops, holm oak Quercus ilex, oak wood ( $Q$. robur, $Q$. petraea and $Q$. pyrenaica), beech $F a$ gus sylvatica, Scots pine (Pinus sylvestris and some P. nigra, Austrian pine), mountain pine, and riverbanks. The forest map was intersected with the SU map, and the dominant category of vegetation was identified in each SU. Information on hunting areas was derived by intersecting a regional hunting map with the SU map, indicating that hunting and non-hunting areas covered $70 \%$ and 

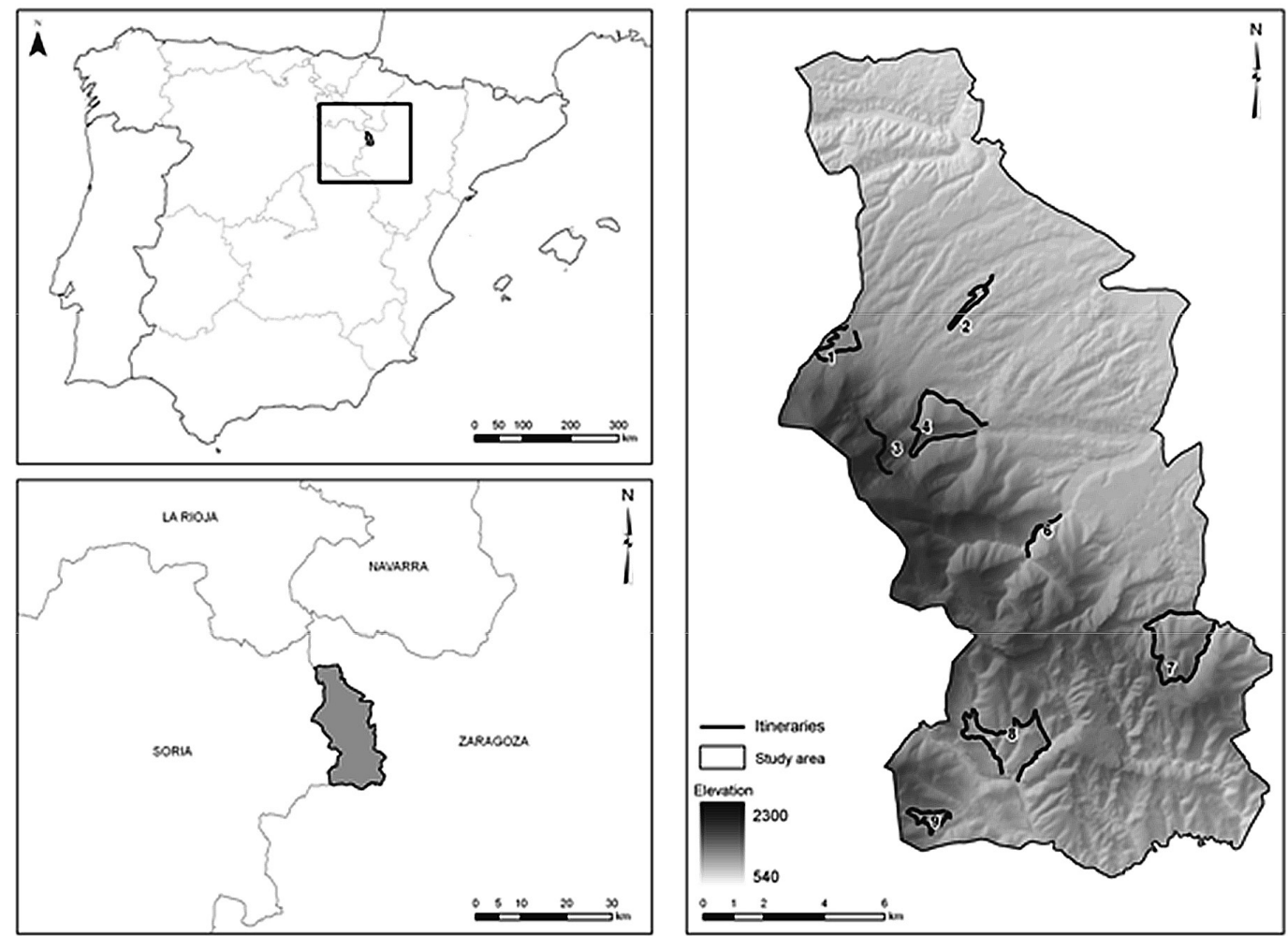

Figure 1: The Moncayo Nature Park (MNP) in the Iberian Peninsula (left) and placement of itineraries (right).

Figura 1: El Parque Natural del Moncayo (PNM) en la Península Ibérica (izquierda) y localización de los itinerarios (derecha).

$30 \%$ of the SU, respectively, which was proportional to the availability of both categories in the study area $(89 \%$ and $11 \%$, respectively). All transformations of the data and maps were performed using RouteSurvey in ArcView GIS 3.2 ® ESRI software.

\subsection{Data analysis}

The data were analysed using Binary Logistic Regression, a generalized linear model procedure that evaluates the relationships between a response variable of binary data and a single or multiple predictor variables. In this study, presence-absence (1-0) of wild boar was the response variable, and vegetation, elevation, hunting activity, year, and season were the predictor variables. An initial full logistic model was subjected to a backward stepwise procedure to identify the variables that contributed significantly to the model. Each predictor variable was tested against its reference variable and the parameters of the model were estimated using the maximum likelihood technique (Doménech \& Navarro, 2005). The statistical significance of individual regression coefficients was assessed using Wald's Statistic, and the overall goodness-of-fit of the model was assessed using the Nagelkerke $\mathrm{R}^{2}$. Analyses were performed using SPSS for Windows ${ }^{\mathrm{TM}}$, v. 17 (2008), and the level for statistical significance was set at $p<0.05$.

\section{Study area}

$\operatorname{MNP}\left(41^{\circ} 46^{\prime} 8^{\prime \prime} \mathrm{N} ; 1^{\circ} 45^{\prime} 15^{\prime \prime} \mathrm{W}\right)$ is a Natura 2000 protected area in Aragon, Spain, and is part of the Iberian mountain system (Figure 1). In the park $(\sim 11,144 \mathrm{ha})$, elevation ranges between $600 \mathrm{~m}$ and $2315 \mathrm{~m}$, and the relief varies from gently rolling to steep slopes. The climate is Mediterranean with a slight continental influence and characterized by dry hot summers, prolonged winters with snowfall at the highest elevations, and an average annual temperature of $10.8^{\circ} \mathrm{C}$. Precipitation occurs mainly during autumn and spring, and mean annual amounts range from $600 \mathrm{~mm}$ at low elevations and $1,000 \mathrm{~mm}$ at high elevations.

Based on differences in elevation and vegetation, there are three sectors in the area (Uribe-Echevarría, 2002). In the meso-Mediterranean sector, where elevation reaches $1.000 \mathrm{~m}$, the predominant vegetation is forests of holm oak, and some kermes oak Quercus coccifera, an understory of rockrose Cistus spp., and agricultural fields of cereals, grapes Vitis vinifera, and olives Olea europaea. The supra-Mediterranean sector which lies between $1000 \mathrm{~m}$ and $1600 \mathrm{~m}$ is characterized by pyrenean oak Quercus pyrenaica, and holm oak. At higher elevations, there are areas of sessile oak Quercus petraea, pedunculated oak Quercus robur, and beech, along with patches of scots pine and austrian pine, and holly Ilex aquifolium is the most common shrub. Above $1600 \mathrm{~m}$, in the oroMediterranean sector, there are scrublands and natural 
pastures. The peaks are populated by juniper Juniperus spp., rockrose, jointfir Ephedra ssp., and stands of mountain pine Pinus uncinata. The predominant vegetation on riverbanks is willow Salix atrocinera, ash Fraxinus excelsior, and birch Betula alba.

Since at least the mid-19th Century, the area has had stable populations of wild boar (Gortázar et al., 2000). Inside the MNP there are nine hunting grounds, managed by local hunters, where the open season runs from October to February. Four isolated non-hunting areas occupy $11 \%$ of the study area (1,514 ha, 120 ha, 77 ha and 83 ha), being the rest huntable. Occasionally, in few hunting areas, small quantities of corn Zea mays are used as bait, but the overall effect on the behaviour and distribution of wild boar is negligible. In the 2006/2007 and 2007/2008 hunting seasons, which had no bag limits, 234 and 295 individuals were harvested. In those years, the species did not inflict significant damages to forests or farmlands, although sporadic culling occurred near the villages, out of the hunting season. Between 2005 and 2008, mast supply was low and, in the 2006/2007 and 2007/2008 seasons, respectively, the densities of wild boar were 2.4 animals $\mathrm{km}^{-2}$ and 3.0 animals km² (Giménez-Anaya et al., 2009).

\section{Results}

On average, in each year, signs of wild boars were found in $24 \%$ of the SU (Table 1), and evidence of rooting $(65 \%)$ and footprints $(27 \%)$ were the most common indicators of its presence. The statistical model $\left(\chi^{2}=408\right.$; d. f. $=15 ; \mathrm{p}<0.0001$, Nagelkerke $\mathrm{R}^{2}=0.19$ ) indicated that the probability of detecting the presence of the species was higher in 2006 and 2007 than it was in 2008 (1.4 and 1.3 times, respectively), and higher during winter, autumn, and spring than in summer $(2.9,2.2$, and 1.8 times, respectively) (Table 2 ). The model indicated that areas of beech $(\operatorname{Exp}(\beta)=4.35)$, holm oak $(\operatorname{Exp}(\beta)=3.27)$, oak wood $(\operatorname{Exp}(\beta)=2.17)$, and Scots pine $(\operatorname{Exp}(\beta)=1.69)$ were used significantly more than expected. There was a negative association (given by the negative $\beta$-parameter) between the presence of wild boar and mountain pine and crops-pastures. Signs of wild boar presence were 3.38 times more likely to be found in non-hunting areas than in

Table 1: Seasonal tracking data of S. scrofa in MNP (2006-2008) using 254 sampling units (SU) per season. Tabla 1: Rastreo estacional de Sus scrofa en el PNM (2006-2008) utilizando 254 unidades de muestreo por estación.

\begin{tabular}{|l|c|c|c|c|}
\hline Season & $\mathbf{2 0 0 6}$ & $\mathbf{2 0 0 7}$ & $\mathbf{2 0 0 8}$ & Total \\
\hline \multirow{2}{*}{ Winter } & 76 & 93 & 71 & - \\
& $29.9 \%$ & $36.6 \%$ & $28 \%$ & $31.5 \%$ \\
\hline \multirow{2}{*}{ Spring } & 81 & 59 & 39 & - \\
& $31.9 \%$ & $23.2 \%$ & $15.4 \%$ & $23.5 \%$ \\
\hline \multirow{2}{*}{ Summer } & 40 & 41 & 35 & - \\
& $15.7 \%$ & $16.1 \%$ & $13.8 \%$ & $15.2 \%$ \\
\hline \multirow{2}{*}{ Autumn } & 74 & 58 & 68 & - \\
& $29.1 \%$ & $22.8 \%$ & $26.8 \%$ & $26.2 \%$ \\
\hline Average & $26.7 \%$ & $24.7 \%$ & $21 \%$ & $24.1 \%$ \\
\hline
\end{tabular}

Table 2: Logistic regression for habitat selection of S. Scrofa in MNP (2006-2008). $\beta$ : estimated coefficient with standard error (SE); Wald is Wald statistics, d.f: degrees of freedom; $\operatorname{Exp}(\beta)$ : odds ratio; C.I.: confidence intervals at $95 \%$.

Tabla 2: Regresión logística para la selección de hábitat de Sus scrofa en el PNM (2006-2008). $\beta$ : coeficiente estimado y su error estándar (ES); Wald es estadístico de Wald, g.l.: grados de libertad; $\operatorname{Exp}(\beta)$ : razón de probabilidades; I.C.: intervalo de confianza al $95 \%$.

\begin{tabular}{|c|c|c|c|c|c|c|c|c|}
\hline & \multirow{2}{*}{$\beta$} & \multirow{2}{*}{ SE } & \multirow{2}{*}{ Wald } & \multirow{2}{*}{ d. $f$} & \multirow{2}{*}{ Sig. } & \multirow{2}{*}{$\operatorname{Exp}(\beta)$} & \multicolumn{2}{|c|}{ C.I. $95 \% \operatorname{Exp}(\beta)$} \\
\hline & & & & & & & Lowest & Upper \\
\hline 2008 & & & 10.295 & 2 & 0.006 & & & \\
\hline 2006 & 0.355 & 0.112 & 9.989 & 1 & 0.002 & 1.427 & 1.145 & 1.778 \\
\hline 2007 & 0.244 & 0.114 & 4.621 & 1 & 0.032 & 1.277 & 1.022 & 1.595 \\
\hline Shrubs & & & 105.966 & 7 & 0.000 & & & \\
\hline Crops-pastures & -0.164 & 0.249 & 0.435 & 1 & 0.509 & 0.849 & 0.521 & 1.382 \\
\hline Holm oak & 1.185 & 0.157 & 56.763 & 1 & 0.000 & 3.272 & 2.404 & 4.454 \\
\hline Beech & 1.470 & 0.249 & 34.779 & 1 & 0.000 & 4.348 & 2.668 & 7.087 \\
\hline Mountain pine & -0.571 & 0.323 & 3.132 & 1 & 0.077 & 0.565 & 0.300 & 1.063 \\
\hline Scots pine & 0.527 & 0.169 & 9.653 & 1 & 0.002 & 1.693 & 1.215 & 2.360 \\
\hline Riverbanks & 0.011 & 0.360 & 0.001 & 1 & 0.975 & 1.011 & 0.500 & 2.046 \\
\hline Oak wood & 0.773 & 0.198 & 15.261 & 1 & 0.000 & 2.166 & 1.470 & 3.191 \\
\hline Non-hunting area & 0.941 & 0.141 & 44.526 & 1 & 0.000 & 2.563 & 1.944 & 3.379 \\
\hline Summer & & & 62.972 & 3 & 0.000 & & & \\
\hline Autumn & 0.766 & 0.138 & 30.891 & 1 & 0.000 & 2.151 & 1.642 & 2.819 \\
\hline Winter & 1.060 & 0.136 & 61.115 & 1 & 0.000 & 2.886 & 2.212 & 3.764 \\
\hline Spring & 0.598 & 0.140 & 18.369 & 1 & 0.000 & 1.819 & 1.384 & 2.392 \\
\hline$<1100 \mathrm{~m}$ & & & 7.561 & 2 & 0.023 & & & \\
\hline $1101-1600 \mathrm{~m}$ & 0.295 & 0.115 & 6.594 & 1 & 0.010 & 1.343 & 1.072 & 1.682 \\
\hline$>1600 \mathrm{~m}$ & 0.356 & 0.191 & 3.477 & 1 & 0.062 & 1.427 & 0.982 & 2.075 \\
\hline Constant & -2.112 & 0.221 & 91.285 & 1 & 0.000 & 0.121 & & \\
\hline
\end{tabular}


hunting areas (based on the upper C.I. 95\% $\operatorname{Exp}(\beta)$. Medium $(1,101-1,600 \mathrm{~m})$ and low $(<1100 \mathrm{~m})$ elevations were used significantly more and less than expected, respectively, all year long.

Habitat use by wild boar varied seasonally. In spring, the probability of finding evidence of the species was highest in areas of holm oak $(\operatorname{Exp}(\beta)=3.25)$ (Table 3); in summer and autumn, the probability of detection was highest in areas of holm oak $(\operatorname{Exp}(\beta)=14.19$; $\operatorname{Exp}$ $(\beta)=2.99)$, oak wood $(\operatorname{Exp}(\beta)=10.25 ; \operatorname{Exp}(\beta)=4.02)$, and beech $(\operatorname{Exp}(\beta)=9.88 ; \operatorname{Exp}(\beta)=6.95)($ Table 3$)$. In winter, areas of holm oak and beech were preferred over the rest of vegetation types. Non-hunting areas were selected over hunting areas in all seasons, except for winter. Elevation had a significant effect on the presence of wild boar in summer, only, when medium (1,101-1,600 m) elevations were used preferentially.

\section{Discussion}

The opportunistic, generalist, and omnivorous habits of wild boar (Acevedo et al., 2006; Abáigar, 1993; Herrero, 2003; Herrero et al., 2006) leads the species to the differential use of habitat depending on elevation, vegetation, and wildlife management strategies. In MNP, in general, wild boar preferred non-hunting areas, medium elevations (1101-1600 m), areas of holm oak, beech, oak wood, and Scots pine, and avoided mountain pine and agricultural areas. This selection of woods with hard mast over shrubs and agricultural areas, has been demonstrated in other studies in European mountain areas (Baubet, 1998; Meriggi \& Sacchi, 1992). Although altitude selection differs from what was observed in Picos de Europa National Park (Nores, 2010), probably due to the dry soil during summer.

The clear association between wild boar signs and behaviour helps to understand how the species selects and uses the habitat (Abáigar et al., 1994; Dardaillon, 1986). Bedding sites can be related to shelter areas, scrapes are associated with fly control and thermoregulation (Groot Bruinderink \& Hazebroek, 1996), and wallows are associated with foraging. Seasonal changes in the use of habitat by wild boar are strongly associated with food availability (Groot Bruinderink \& Hazebroek, 1996). In our study, holm oak was the most important vegetation type for wild boar, especially in spring. In addition, beech, oak woods, and patches of Scots pine were important habitats for wild boar in summer, autumn, and winter. In autumn and winter, wild boar tend to forage on acorns, beechnuts, and chestnuts, when they are available (Herrero et al., 2005; Irizar et al., 2004), and preferring deciduous forests during years of mast production (Herrero, 2003).

A variety of factors likely contributed to the fewer number of signs observed in summer. First, if the soil is too dry,

Table 3. Logistic regression for the seasonal habitat selection of S. scrofa in MNP (2006-2008). $\beta$ : estimated coefficient, Exp ( $\beta$ ):odds ratio; d. f: degrees of freedom.

Tabla 3. Regresión logística para el uso estacional del hábitat por S. scrofa en el PNM (2006-2008). $\beta$ : coeficiente estimado, Exp ( $\beta$ ): razón de probabilidades; g. l. grados de libertad.

\begin{tabular}{|c|c|c|c|c|c|c|c|c|}
\hline & \multicolumn{2}{|c|}{ Spring } & \multicolumn{2}{|c|}{ Summer } & \multicolumn{2}{|c|}{ Autumn } & \multicolumn{2}{|c|}{ Winter } \\
\hline & Sig. & $\operatorname{Exp}(\beta)$ & Sig. & $\operatorname{Exp}(\beta)$ & Sig. & $\operatorname{Exp}(\beta)$ & Sig. & $\operatorname{Exp}(\beta)$ \\
\hline 2006 & .000 & & .690 & & .222 & & .067 & \\
\hline 2007 & .025 & .623 & .874 & 1.043 & .086 & .682 & .086 & 1.408 \\
\hline 2008 & .000 & .358 & .509 & .834 & .550 & .878 & .630 & .906 \\
\hline Shrubs & .000 & & .001 & & .000 & & .000 & \\
\hline Crops-pastures & .539 & .748 & .077 & 4.185 & .550 & 1.305 & .056 & .378 \\
\hline Holm oak & .000 & 3.248 & .000 & 14.191 & .001 & 2.996 & .000 & 2.646 \\
\hline Beech & .228 & 1.831 & .002 & 9.881 & .000 & 6.949 & .000 & 6.003 \\
\hline Mountain pine & .871 & .910 & .897 & 1.172 & .045 & .116 & .405 & .657 \\
\hline Scots pine & .694 & .870 & .016 & 4.987 & .017 & 2.190 & .028 & 1.871 \\
\hline Riverbanks & .949 & .958 & .245 & 3.998 & .391 & .405 & .810 & 1.140 \\
\hline Oak wood & .416 & .707 & .001 & 10.246 & .000 & 4.016 & .115 & 1.742 \\
\hline$<1100 \mathrm{~m}$ & .554 & & .061 & & .319 & & .364 & \\
\hline $1101-1600 \mathrm{~m}$ & .294 & 1.277 & .018 & 1.992 & .476 & 1.173 & .190 & 1.310 \\
\hline$>1600 \mathrm{~m}$ & .914 & 1.044 & .292 & 1.718 & .133 & 1.708 & .321 & 1.403 \\
\hline Non hunting area & .000 & 3.610 & .000 & 4.635 & .000 & 2.556 & .103 & 1.515 \\
\hline$\chi^{2}$ & 83.4 & & 130.1 & & 133.9 & & 81.4 & \\
\hline d.f. & 12 & & 12 & & 12 & & 12 & \\
\hline Sig. & $<0.001$ & & $<0.001$ & & $<0.001$ & & $<0.001$ & \\
\hline Nagelkerke $\mathrm{R}^{2}$ & 0.156 & & 0.273 & & 0.236 & & 0.142 & \\
\hline
\end{tabular}


it becomes too difficult for wild boar to find and extract underground food and they shift to grazing, which depicts a change in the diet (Abáigar, 1993). Second, the fewer number of signs can reflect a constriction of the home ranges to areas mainly of beech and oak woods, where more water is available and the soil is less dry, thus, more easily rooted (Boitani et al., 1994). In addition, it might be associated with migratory movements in search for food in areas outside of the study area (Abáigar et al., 1994; Dardaillon 1986; Singer \& Ackerman, 1981). Finally, footprints are less likely to be found in dry soil. Our study also found that wild boar avoided agricultural fields in all seasons (see also Thrufjell et al., 2009), apparently, because of seasonal limitations in food availability (Acevedo et al., 2006).

The selection of non-hunted areas suggests that hunting had a significant influence on the behaviour and distribution of the species, either by forcing animals to avoid areas where disturbance was greatest or simply by reducing its presence and controlling population density as a result of the death of individuals, as demonstrated before (Herrero et al., 2006). Keuling et al., (2008) showed that hunting pressure affected wild boar activity, by allowing the species to increase its diurnal activity in undisturbed feeding habitats. Scillitani et al. (2010) observed that with a low hunting pressure wild boars moved less than $1 \mathrm{~km}$, but if it increased it could reach up to $8 \mathrm{~km}$. Hunting pressure in MNP can be considered as not very high. The existence of non-hunting areas inside the protected area, allows a higher presence of the main game species in this specific areas as they are all adjacent to hunted areas, and have small dimensions, and are easily detectable by wild boars (Tolon et al. 2008, 2009). In the absence of any significant damages to forests or agricultural lands, this result must not lead to the opening of these areas to hunting, but to a close monitoring of wild boar populations, especially habitat and food availability and preferences as well as their impact on other wildlife species, particularly ground-nesting birds (Giménez-Anaya et al., 2006; Carpio et al., 2016).

Given that wild boar have nocturnal habits, exhibit behaviours that make them elusive, and are sensitive to the presence of humans (Acevedo et al., 2006; Abáigar et al., 1994), we conclude that indirect signs are a reliable, cost-effective means of monitoring habitat use by this species Abáigar et al., 1994; Evans, 2006). Finally, the availability of permanent refuges and management strategies, particularly, the delimitation of non-hunting areas, are important factors that influence wild boar habitat use (Herrero et al., 2006; Keuling et al., 2008).

\section{Acknowledgments}

This research is part of the long-term Ecological Monitoring of MNP and was funded by the Government of Aragon through several consultancy projects. We are grateful to E. Arrechea, technician of the park, who directed and assisted the project, and to the park rangers who assisted in the fieldwork. The first author was granted a Leonardo da Vinci Fellowship PT/06/A/F/PL-126308.

\section{References}

Abáigar, T., 1993. Régimen alimentario del jabalí (Sus scrofa, L. 1758) en el sureste ibérico. Doñana, Acta Vertebrata, 20(1): 35-48.

Abáigar, T., Del Barrio, G. \& Vericad, J.R., 1994. Habitat preference of wild boar (Sus scrofa L., 1758) in a Mediterranean environment. Indirect evaluation by signs. Mammalia, 58: 201-210. http://dx.doi.org/10.1515/mamm.1994.58.2.201.

Acevedo, P., Escudero, M.A., Muñoz, R. \& Gortázar, C., 2006. Factors affecting wild boar abundance across an environmental gradient in Spain. Acta Theriologica, 51(3): 327336. http://dx.doi.org/10.1007/BF03192685.

Apollonio, M., Andersen, R. \& Putman, R.J., 2010. European Ungulates and their Management in the 21st Century. Cambridge University Press. Cambridge, UK.

Barbosa, A.M., Vargas, J.M., Farfán, M.A., Real, R. \& Guerrero, J.C. 2004. Caracterización del aprovechamiento cinegético de los mamíferos en Andalucía. Galemys, 16(1): 41-59.

Baubet, E. 1998. Biologie du sanglier en montagne: biodémographie, occupation de l'espace et régime alimentaire. Thèse de Doctorat, L'Université Claude Bernard-Lyon 1.

Boitani, L., Mattei, L., Nonis, D. \& Corsi, F., 1994. Spatial and activity patterns of wild boar in Tuscany, Italy. Journal of Mammalogy, 75: 600-612. http://dx.doi.org/10.2307/1382507.

Carpio A.J., Hillström, L., Tortosa, F.S., 2016. Effects of wild boar predation on nests of wading birds in various Swedish habitats. European Journal of Wildlife Research, (in press). $\mathrm{http} / / / \mathrm{dx}$. doi.org/10.1007/s10344-016-1016-y.

Carvalho, P., Nogueira, A., Soares, A.M.V.M. \& Fonseca, C., 2008. Ranging behaviour of translocated roe deer in a Mediterranean habitat: seasonal and altitudinal influences on home range size and patterns of range use. Mammalia, 72: 89-94. http://dx.doi.org/10.1515/MAMM.2008.019.

Dardaillon, M., 1986. Seasonal variations in habitat selection and spatial distribution of wild boar (Sus scrofa) in the Camargue, Southern France. Behavioural Processes, 13: 251-268. http://dx.doi.org/10.1016/0376-6357(86)90088-4.

Doménech, J.M. \& Navarro, J.B., 2005. Regresión logística binaria, multinomial y de Poisson. Signo, Barcelona.

Evans, J.W., 2006. Observer error in identifying species using indirect signs: analysis of a river otter track survey technique. MSc Dissertation, Texas A\&M University.

Farina, A., 1991. Recent changes in the mosaic patterns in a montane landscape (north Italy) and consequences on vertebrate fauna. Options Méditerranéennes - Série Séminaires, 15: 121-134.

Fernández-Llario, P. \& Mateos-Quesada, P., 2003. Population structure of the wild boar (Sus scrofa) in two Mediterranean habitats in the western Iberian Peninsula. Folia Zoologica, 52(2): 143-148.

Fernández-Llario, P. \& Mateos-Quesada, P., 2005. Influence of rainfall on the breeding biology of wild boar (Sus scrofa) in a Mediterranean ecosystem. Folia Zoologica, 54(3): 240-248.

Giménez-Anaya, A., Herrero, J., Couto, S., Rosell, C. \& GarcíaSerrano, A., 2006. Food habits of wild boar (Sus scrofa) in a Mediterranean coastal wetland. Wetlands, 28(1):197-203. $\mathrm{http}: / / \mathrm{dx}$.doi.org/10.1672/07-18.1.

Giménez-Anaya, A., Revilla, R., Prada, C., Arnal, M.C., GarcíaSerrano, A., Martínez, D., Fernández de Luco, D. \& Herrero, J., 2009. El jabalí Sus scrofa y su caza en el Parque Natural del Moncayo. Un ejemplo de seguimiento poblacional en un espacio natural protegido. Naturaleza Aragonesa, 22: 20-25.

Gortázar, C., Herrero, J., Villafuerte, R. \& Marco J., 2000. Historical examination of the status of large mammals in Aragón, Spain. Mammalia, 64: 411-422. http://dx.doi. org/10.1515/mamm.2000.64.4.411. 
Goulding, M.J., Roper, T.J., Smith, G.C. \& Baker, S.J., 2003. Presence of free-living wild boar Sus scrofa in southern England. Wildlife Biology, 223: 631-648.

Groot Bruinderink, G.W.T.A. \& Hazebroek, E., 1996. Wild boar (Sus scrofa scrofa L.) rooting and forest regeneration on podzolic soils in the Netherlands. Forest Ecology and Management, 88: 71-80. http://dx.doi.org/10.1016/S0378-1127(96)03811-X.

Herrero, J., 2003. Adaptación funcional del jabalí a un ecosistema forestal y a un sistema agrario intensivo en Aragón. Publicaciones del Consejo de Protección de la Naturaleza de Aragón. Serie Investigación, 41, Zaragoza.

Herrero, J., Irizar, I., Laskurain, N.A., García-Serrano, A. \& García González, R., 2005. Fruits and roots: wild boars foods during the cold season in the southwestern Pyrenees. Italian Journal of Zoology, 72: 49-52. http://dx.doi. org/10.1080/11250000509356652.

Herrero, J., Prada, C., García-Serrano, A., \& Fernandéz-Arberas, O., 2006. Mamíferos de Guara. Publicaciones del Consejo de Protección de la Naturaleza de Aragón. Serie Difusión, Zaragoza.

Irizar, I., Laskurain, N.A. \& Herrero, J., 2004. Wild boar frugivory in the Atlantic Basque Country. In: Fonseca, C., Herrero, J., Luís, A., \& Soares, A. M. V. M., (ed) Wild boar Research 2002. A selection and edited papers from the 4th International Wild boar Symposium. Galemys, 16 Special Issue: $125-134$

Keuling, O., Stier, N. \& Roth, M., 2008. How does hunting influence activity and spatial usage in wild boar Sus scrofa L. European Journal of Wildlife Research, 54: 729-737. http:// dx.doi.org/10.1007/s10344-008-0204-9.

Krebs, J.R. \& Davies, N.B., 1997. Behavioural Ecology: An evolutionary approach. Blackwell Science. Oxford.

Macdonald, D., 2001. The new encyclopedia of mammals. Oxford University Press, Oxford.

Massei, G. \& Genov, P., 1995. Preliminary analysis of food availability and habitat use by the wild boar in a Mediterranean area. Ibex, Journal of Mountain Ecology, 3: 168-170.

Massei, G. \& Genov, P., 2004. The environmental impact of wild boar. Galemys, 16: 135-145.

Melis, C., Szafrańska, P.A., Jędrzejewska, B. \& Bartoń, K., 2006. Biogeographical variation in the population density of wild boar (Sus scrofa) in western Eurasia. Journal of Biogeography, 33: 803-811. http://dx.doi.org/10.1111/j.1365-2699.2006.01434.x.

Meriggi, A. \& Sacchi, O., 1992. Habitat selection by wild boar in Northern Apennines (N-Italy). Pp: 435-438. In: Spitz, F., Janeau, G., Gonzalez, G., \& Aulagnier, S. (Eds), Ongulés/ Ungulates. IRGM, Paris.

Morse, B.W., Nibbelink, N.P., Osborn, D.A., \& Miller, K.V., 2009. Home range and habitat selection of an insular fallow deer (Dama dama L.) population on Little St. Simons Island, Georgia, USA. European Journal of Wildlife Research, 55: 325-332. http://dx.doi.org/10.1007/s10344-008-0245-0.

Mysterud, A., 1999. Seasonal migration pattern and home range of roe deer (Capreolus capreolus) in an altitudinal gradient in southern Norway. Journal of Zoology, 247: 479-486. http://dx.doi.org/10.1111/j.1469-7998.1999.tb01011.x.
Mysterud, A. \& Ims, R.A., 1998. Functional responses in habitat use: availability influences relative use in trade-off situations. Ecology, 79(4): 1435-1444. http://dx.doi.org/10.1890/00129658(1998)079[1435:FRIHUA]2.0.CO;2.

Nores, C., González, F. \& García, P., 1995. Wild boar distribution trends in the last two centuries: an example in Northern Spain. Ibex, Journal of Mountain Ecology, 3: 137-140.

Nores, C. 2010. Wild boar abundance and altitude. 8 th International symposium on wild boar and other suids. Book of abstracts. York UK 1-4 September 2010: FERADEFRA.

Orians, G.H. \& Wittenberger, J.F., 1991 Spatial and temporal scales in habitat selection. American Naturalist, 137: 29-49. http://dx.doi.org/10.1086/285138.

Sáez-Royuela, C. \& Tellería, J.L., 1986. The increased population of the wild boar (Sus scrofa L.) in Europe. Mammal Review, 16(2): 97-101. http://dx.doi.org/10.1111/j.1365-2907.1986. tb00027.x.

Scillitani, L., Monaco, A. \& Toso S., 2010. Do intensive drive hunts affect wild boar (Sus scrofa) spatial behaviour in Italy? Some evidences and management implications. European Journal of Wildlife Research, 56(3): 307-318. http:// dx.doi.org/10.1007/s10344-009-0314-z.

Singer, F.J. \& Ackerman, B.B., 1981. Food availability, reproduction, and condition of European wild boar in Great Smoky Mountains National Park. U.S. Department of the Interior, National Park Service Southeast Region.

Tellería, J.L. \& Sáez-Royuela, C., 1985. L'évolution demographique du sanglier (Sus scrofa) en Espagne. Mammalia, 49(2): 195202. http://dx.doi.org/10.1515/mamm.1985.49.2.195.

Thrufjell, H., Ball, J.P., Åhlén, P., Kornacher, P., Dettki, H. \& Sjöberg, K., 2009. Habitat use and spatial patterns of wild boar Sus scrofa (L.): agricultural fields and edges. European Journal of Wildlife Research, 55(5): 517-523. http://dx.doi. org/10.1007/s10344-009-0268-1.

Tolon, V., Baubet E., Gaulard P., Pasquier J. J., Hebeiser C., Fischer C. \&. Dobremez J. F. 2008. Comportement du sanglier en réponse à la pression de chasse. Influence des "reserves" sur son occupation de l'espace. In: F. Klein, B. Guibert and E. Baubet (Eds.). Modalités de gestion du sanglier. Actes du colloque tenu à Reims (Marne) 1-2 March 2007. FNC-ONCFS: 172-181, Paris.

Tolon, V., Dray S., Loison A., Zeileis A., Fischer C. \& Baubet. E. 2009. Responding to spatial and temporal variations in predation risk: Space use of a game species in a changing landscape of fear. Canadian Journal of Zoology, 87(12): 1129-1137. http://dx.doi.org/10.1139/Z09-101.

Uribe-Echevarría, D.P.M., 2002. Vegetación e itinerarios botánicos en el Parque Natural del Moncayo. Publicaciones del Consejo de Protección de la Naturaleza de Aragón, Zaragoza, España.

Zamora, R., Gómez Sal, A., Soriguer, R., Fernández-Haeger, J., Jordano, D. \& Jordano, P., 1996. Herbivoría en espacios protegidos. Ecosistemas, 18: 70-71. 